\title{
1 COVID-19 Related Chemosensory Changes in Individuals with Self-Reported Obesity
}

3 Authors: Bhutani, S., Coppin, G., Veldhuizen, MG., Parma, V., Joseph, PV

\section{Author Affiliations:}

5 Surabhi Bhutani, School of Exercise and Nutritional Sciences, San Diego State University, San

6 Diego, CA

7 Géraldine Coppin, Department of Psychology, Formation Universitaire à Distance

8 (UniDistance), Brig, Switzerland; Swiss Center for Affective Sciences, University of Geneva,

9 Geneva, Switzerland; geraldine.coppin@unige.ch

10 Maria Geraldine Veldhuizen, Department of Anatomy, Faculty of Medicine, Mersin University,

11 Mersin, Turkey; margaveldhuizen@gmail.com

12 Valentina Parma, Department of Psychology, Temple University; Monell Chemical Senses

13 Center; valentina.parma@temple.edu

14 Paule Valery Joseph, National Institutes of Alcohol Abuse and Alcoholism and National Institute

15 of Nursing Research paule.joseph@nih.gov

\section{Contact Information:}

18 Surabhi Bhutani, PhD

19 School of Exercise and Nutritional Sciences

20 San Diego State University

21 ENS Building, room 302

225500 Campanile drive

23 San Diego, CA 92182 
medRxiv preprint doi: https://doi.org/10.1101/2021.02.28.21252536; this version posted March 3, 2021. The copyright holder for this preprint

(which was not certified by peer review) is the author/funder, who has granted medRxiv a license to display the preprint in perpetuity.

This article is a US Government work. It is not subject to copyright under 17 USC 105 and is also made available for use under a CCO license.

24 Phone: 619-594-4094

25 sbhutani@sdsu.edu

27 Running Title: COVID-19 chemosensory decline in obesity

28 Word Count: 4000

29 Funding: Deployment of the GCCR survey was supported by an unrestricted gift from James

30 and Helen Zallie to support sensory science research at Penn State. Paule V. Joseph is supported

31 by the National Institute of Alcohol Abuse and Alcoholism and the National Institute of Nursing

32 Research. PVJ is also supported by the Office of Workforce Diversity, National Institutes of

33 Health, and the Rockefeller University Heilbrunn Nurse Scholar Award. Maria G. Veldhuizen is

34 supported by the 2232 International Fellowship for Outstanding Researchers Program of

35 TÜBİTAK under award number $118 C 299$.

36 Disclosures:

37 Competing interests: The authors declare no competing financial interests in relation to the

38 work described.

Author Contributions:

41 All authors conceived the project idea. MGV and VP analyzed the data. SB, GC, PJ drafted the

42 manuscript. All authors were involved in editing the paper and had final approval of the

43 submitted and published versions. 
medRxiv preprint doi: https://doi.org/10.1101/2021.02.28.21252536; this version posted March 3, 2021. The copyright holder for this preprint (which was not certified by peer review) is the author/funder, who has granted medRxiv a license to display the preprint in perpetuity.

This article is a US Government work. It is not subject to copyright under 17 USC 105 and is also made available for use under a CCO license.

\section{Abstract}

48 Background/objectives: Individuals with obesity show alterations in smell and taste abilities.

49 Smell and taste loss are also the most prominent neurological symptoms of COVID-19, yet how

50 chemosensory ability present in individuals with obesity with a positive COVID-19 diagnosis is

51 unknown.

52 Subjects/Methods: In this secondary analysis of a cross-sectional global dataset, we compared

53 self-reported chemosensory ability in participants with a respiratory illness reporting a positive

$54(\mathrm{C} 19+; \mathrm{n}=5156)$ or a negative $(\mathrm{C} 19-; \mathrm{n}=659)$ COVID-19 laboratory test outcome, who also

55 self-reported to be obese $(\mathrm{C} 19+; \mathrm{n}=433, \mathrm{C} 19-; \mathrm{n}=86)$ or non-obese.

56 Results: Compared to the C19- group, C19+ exhibited a greater decline in smell, taste, and

57 chemesthesis during illness, though these symptoms did not differ between participants with

58 obesity and without obesity. In $68 \%$ of participants who reported recovery from respiratory

59 illness symptoms ( $\mathrm{n}=3431 \mathrm{C} 19+$ and $\mathrm{n}=539 \mathrm{C} 19-)$, post-recovery chemosensory perception did

60 not differ in C19+ and C19- diagnosis, and by self-reported obesity. Finally, we found that all

61 chemosensory and other symptoms combined predicted the C19+ diagnosis in participants with

62 obesity with a moderately good estimate (63\% accuracy). However, in C19+ participants with

63 obesity, we observed a greater relative prevalence of non-chemosensory symptoms, including

64 respiratory as respiratory and GI symptoms.

65 Conclusions: We conclude that despite a presumed lower sensitivity to chemosensory stimuli,

66 COVID-19 respondents with obesity experience a similar self-reported chemosensory loss as

67 those without obesity, and in both groups self-reported chemosensory symptoms are similarly

68 predictive of COVID-19.

69 Keywords: COVID-19; Smell; Taste; Chemesthesis; Obesity 
medRxiv preprint doi: https://doi.org/10.1101/2021.02.28.21252536; this version posted March 3, 2021. The copyright holder for this preprint

(which was not certified by peer review) is the author/funder, who has granted medRxiv a license to display the preprint in perpetuity.

This article is a US Government work. It is not subject to copyright under 17 USC 105 and is also made available for use under a CCO license.

\section{INTRODUCTION}

According to the World Health Organization, globally $13 \%$ of adults aged 18 years and

72 over reported to have obesity in 2016 (1). Within the context of the ongoing COVID-19

73 pandemic, intriguingly, countries with the highest prevalence of obesity also recorded a high

74 death rate from COVID-19 infection (2). Although, an increased in susceptibility to viral

75 infection with obesity is unknown, a recent review by Stefan et al. concluded that obesity is a

76 strong and independent determinant of morbidity and mortality in patients infected with SARS-

77 CoV-2, the virus responsible for COVID-19 infection (3). A recent analysis also indicated that

78 COVID-19 mortality in patients with obesity is higher than that of other comorbidities, including

79 diabetes, hypertension, asthma, and cancer (4). In addition to greater risk for COVID-19 related

80 poor health outcomes $(3,5,6)$, patients with obesity are more likely to require hospitalization,

81 especially in young adults with a Body Mass Index (BMI) $>30 \mathrm{~kg} / \mathrm{m}$ (7). Overall, current

82 evidence suggests that obesity significantly interacts with the pathogenesis of COVID-19.

83 Despite this risk, COVID-19 chemosensory symptoms have not yet been systematically assessed

84 in this population group.

85 Disturbances in smell and taste emerged as a predominant neurological symptom of

86 COVID-19 infection, with 77 percent of COVID-19 patients reporting sudden olfactory and

87 gustatory dysfunctions in a recent meta-analysis (8). In a recent analysis, we also reported

88 quantified smell loss as the best predictor of COVID-19, compared to other common non-

89 chemosensory symptoms (9). However, these studies did not delineate COVID-19-related

90 chemosensory impact in patients with obesity. This is especially important because individuals

91 with obesity typically have existing lower taste sensitivity, and lower capacity to detect and

92 identify odors than individuals without obesity (10). Particularly, excessive body weight has 
medRxiv preprint doi: https://doi.org/10.1101/2021.02.28.21252536; this version posted March 3, 2021. The copyright holder for this preprint

(which was not certified by peer review) is the author/funder, who has granted medRxiv a license to display the preprint in perpetuity.

This article is a US Government work. It is not subject to copyright under 17 USC 105 and is also made available for use under a CCO license.

93 been shown to be associated with impaired taste for sweet and salty foods, alteration in fat/fatty

94 acid-sensing, reduced ability to identify correct taste (11-13) in taste detection thresholds (11-

95 15). These obesity-related chemosensory dysfunctions are driven by production of pro-

96 inflammatory factors from adipose tissues, leading to impairment in olfactory receptors (16) and

97 a decline in taste bud and taste progenitor cells $(17,18)$, respectively. Considering that marked

98 inflammation with obesity also seems to favor viral infections $(19,20)$, the interaction between

99 existing chemosensory deficiency in adults with obesity and COVID-19 related chemosensory

100 impairments are unknown.

101 Existing gustatory and olfactory sensory deficiency due to obesity may mask the viral-

102 induced diminished taste and smell self-reported experiences, leading to a higher portion of

103 undetected cases in this population (21), we need a better understanding of how chemosensory

104 profile changes in patients with obesity. Furthermore, in light of the potential for using oro-naso

105 sensory perception as an early marker of SARS-CoV-2 infection (22-24), it needs to be assessed

106 whether the predictive relation between the chemosensory loss and COVID-19 illness

107 generalizes to participants with obesity. With continually increasing death rates projected well

108 into 2021 using a second statistical model (25), and a wave of infections sweeping through

109 countries worldwide, it is imperative to understand the impact of SARS-COV-2 virus on

110 chemosensory dysfunction in COVID-19 patients in the high-risk category such as populations

111 with excessive body weight. Here, we systematically describe and compare the chemosensory

112 perception (smell, taste, and chemesthesis) and related symptomatology in COVID-19 in non-

113 hospitalized adults with or without self-reported obesity. Following our pre-registered analysis

114 plan (26), we hypothesized that the participants with obesity will report less smell loss during 
medRxiv preprint doi: https://doi.org/10.1101/2021.02.28.21252536; this version posted March 3, 2021. The copyright holder for this preprint

(which was not certified by peer review) is the author/funder, who has granted medRxiv a license to display the preprint in perpetuity.

This article is a US Government work. It is not subject to copyright under 17 USC 105 and is also made available for use under a CCO license.

115 COVID-19 illness. We also hypothesize that smell loss will be less predictive of COVID-19

116 diagnosis than the participants without obesity.

118 METHODS

\section{Study Design}

To the best of our knowledge, this study is the first to assess chemosensory alterations in

121 adults with obesity and COVID-19. We conducted a secondary analysis of cross-sectional

122 survey data collected between April 7th and November 4th, 2020 using the Global Consortium

123 for Chemosensory Research (GCCR) core questionnaire. This crowdsourced survey collected

124 data from community-dwelling individuals via social and traditional media as well as the GCCR

125 website. It was also presented to clinicians to relay to their patients. This survey, currently

126 deployed in 32 languages, used binary-response and categorical questions, as well as visual

127 analog scales to measure self-reported chemosensory ability and other symptoms in adults with

128 ongoing or recent respiratory illnesses (22). We also collected self-reported data on the presence

129 of pre-existing diseases, including our condition of interest, obesity, as well as other COVID-19

130 symptoms All participants included in the study were: 1) $\geq 18$ years old, 2) had a (suspected)

131 respiratory illness within the past two weeks, 3) had onset of respiratory illness after January 1,

132 2020,4) reported COVID-19 diagnosis via laboratory test (viral PCR or antigen test).

133 Respondents who did not report having any illness or symptoms within the last two weeks, who

134 had multiple responses, or who responded "Don't know" or "Other" when asked about their

135 diagnosis of COVID-19, were excluded from the analyses. To investigate the recovery of

136 chemosensory functions, only participants who reported the date of onset of respiratory illness

137 symptoms were included. The original study was approved by the Office of Research Protections 
medRxiv preprint doi: https://doi.org/10.1101/2021.02.28.21252536; this version posted March 3, 2021. The copyright holder for this preprint (which was not certified by peer review) is the author/funder, who has granted medRxiv a license to display the preprint in perpetuity.

This article is a US Government work. It is not subject to copyright under 17 USC 105 and is also made available for use under a CCO license.

138 of The Pennsylvania State University (STUDY00014904). The hypotheses and analyses in this

139 manuscript were pre-registered at https://osf.io/xf25v (26) and the research compendium

140 including data files and analysis scripts is available at https://osf.io/rbcty/. Specifically, our

141 analyses aimed to describe chemosensory perception and related symptomatology during the

142 COVID-19 illness (Aim 1) and post-vs pre-COVID-19 diagnosis (Aim 2), in participants with

143 self-reported obesity vs without obesity. We predicted lower ratings for smell, taste, and

144 chemesthesis, and more severe COVID-19 symptoms in participants with obesity, compared to

145 without obesity. We also speculated smaller differences in ratings for smell, taste, and

146 chemesthesis perception post- vs pre- COVID diagnosis in participants with self-reported

147 obesity. Post-COVID-19 chemosensory recovery (Aim 3) was also tested, hypothesizing that

148 participants will have lower ratings for smell, taste, and chemesthesis post-COVID-19 recovery

149 in participants with self-reported obesity vs without obesity. Additionally, we assessed COVID-

15019 severity as measured based on the sum of reported symptoms (Aim 4), and the ability of smell

151 ratings to predict COVID-19 diagnosis (Aim 5), in participants with self-reported obesity vs

152 without obesity.

153 A departure from the pre-registered analyses is the inclusion of age as a factor in all

154 analyses, following differences in age we observed between groups. We also report the

155 unregistered analysis of pre-illness ratings, an important addition given the previously reported

156 decreased sensitivity for participants with obesity compared to those without obesity.

\section{Participant Description}

A convenience sample of 52334 volunteers accessed the GCCR questionnaire. Of those

160 individuals, 5815 met the inclusion and exclusion eligibility criteria and were included in the 
medRxiv preprint doi: https://doi.org/10.1101/2021.02.28.21252536; this version posted March 3, 2021. The copyright holder for this preprint

(which was not certified by peer review) is the author/funder, who has granted medRxiv a license to display the preprint in perpetuity.

This article is a US Government work. It is not subject to copyright under 17 USC 105 and is also made available for use under a CCO license.

161 final analysis. A positive COVID-19 diagnosis (C19+) was determined using the self-reported

162 data from COVID-19 lab test or clinical exam outcome. All C19+ patients were further

163 categorized into having obesity if they reported it as one of the pre-existing disease conditions in

164 the questionnaire. C19+ patients who did not report having any medical condition or did not

165 answer this question on pre-existing disease conditions were categorized as controls without

166 obesity. We also included a control group of participants without obesity. See Figure 1. for a

167 flow diagram of the inclusion of participants into the various groups.

169 Statistical Analyses

170 Statistical analyses were conducted in R (27) via RStudio. The annotated scripts, the

171 information on the computational environment, and dependencies shared for future

172 reproducibility will be found, upon acceptance of the manuscript, at the OSF project link, which

173 includes directions to the GitHub page at which the code is stored.

174 No negative value appeared in the survey responses. Whenever in question 38 (prior conditions),

175 no response was provided or the option "None" was checked, the response was imputed as

176 indicating no prior conditions. Prediction targets were never imputed. All open-ended questions

177 were excluded as they are incompatible with model generalization.

Demographics

Cognizant of possible null effects in all our analyses, we opted to implement a Bayesian

181 approach, which allows us to estimate the strength of the evidence supporting the null

182 hypothesis. To test via a between-participant sequential Bayes factor design whether a difference

183 between groups was present (H1) or absent (H0), we conducted Bayesian linear regressions with 
medRxiv preprint doi: https://doi.org/10.1101/2021.02.28.21252536; this version posted March 3, 2021. The copyright holder for this preprint (which was not certified by peer review) is the author/funder, who has granted medRxiv a license to display the preprint in perpetuity. This article is a US Government work. It is not subject to copyright under 17 USC 105 and is also made available for use under a CCO license.

184 the lmBF function from the BayesFactor package (28). We used the default Cauchy prior on the

185 effect sizes under the H1 as the scale parameter spread, which was set at its default value of $\mathrm{r}=$ 186 sqrt (2)/2. To test for a difference in age between groups, we used the following full model: Age

$187 \sim$ COVID diagnosis + Obesity Age + COVID diagnosis x Obesity. Additive models (no

188 interaction) and main effect models were also computed and compared to determine the model

189 that best explained the data pattern, aka the model comparison with the most extreme Bayes

190 Factor. Please refer to Supplementary Table 1 for the inference rules, which follows the

191 classification scheme proposed by Lee and Wagenmakers (29) and adjusted from (30). To

192 interpret the strength and the direction of the effects identified, we have additionally sampled

193 from the models' posterior distributions (iterations $=1 \mathrm{e} 4)$. To test for gender differences between

194 groups, we calculated probability tables of women and men in each of the COVID-19 and

195 obesity groups and tested for distribution differences with Pearson's chi-square tests with the R

196 base function "prop.test". We used an alpha of 0.05 to determine significance.

Self-reported Chemosensory perception analyses

For chemosensory perception analyses, we also conducted Bayesian linear regressions

200 with the $1 \mathrm{mBF}$ function. The full model included the following terms: Dependent variable

201 COVID diagnosis + Obesity Age + COVID diagnosis x Obesity. Additive models (no

202 interaction) and main effect models were also computed and compared to determine the model

203 that best explained the data pattern. Age was included in all models to factor in significant

204 associations between age and obesity. We used "before illness", "during illness", "change due to

205 illness" ("before illness" minus "during illness") and "recovery" ("after illness" minus "during

206 illness") separately as dependent variables. 
medRxiv preprint doi: https://doi.org/10.1101/2021.02.28.21252536; this version posted March 3, 2021. The copyright holder for this preprint

(which was not certified by peer review) is the author/funder, who has granted medRxiv a license to display the preprint in perpetuity.

This article is a US Government work. It is not subject to copyright under 17 USC 105 and is also made available for use under a CCO license.

Other illness symptomatology analyses

To assess whether participants with obesity experience more and/or different symptoms

210 from those without obesity, we summed all symptoms that participants reported (each symptom

211 that was reported was assigned a value of 1). We then conducted Bayesian linear regressions

212 with the $1 \mathrm{mBF}$ function as above with summed symptoms as the dependent variable (as above in

213 the chemosensory analyses). We operationalized disease duration as the number of days since

214 onset of the illness and used "days since onset" as the dependent variable in Bayesian linear

215 regression (models as above). For the subset of COVID-19 patients only, we calculated

216 probability tables for the likelihood of experiencing a given symptom for the participants with

217 and without obesity and tested for distribution differences with chi-square tests (details as above

218 under demographics). We used an alpha of 0.05 to determine significance.

\section{Model accuracy for predicting COVID-19 illness}

To deal with binary classification problems in the presence of imbalanced classes, we

222 used the ROSE (Random Over-Sampling Examples) package (31), which generates synthetic

223 balanced samples and thus allows to strengthen the subsequent estimation of any binary

224 classifier. To measure model quality, receiver operating characteristic (ROC) were visualized via

225 the pROC package (32) based on the calculation of hold-out area under the curve (AUC), which

226 summarizes the tradeoff between sensitivity (fraction of correctly identified C19+ cases in the

227 sample with obesity and without obesity) and specificity (fraction of correctly identified C19-

228 cases in the sample with obesity and without obesity) as the threshold value for the predictor is

229 varied. We used symptoms (binary), number of symptoms, chemosensory ratings during illness, 
medRxiv preprint doi: https://doi.org/10.1101/2021.02.28.21252536; this version posted March 3, 2021. The copyright holder for this preprint

(which was not certified by peer review) is the author/funder, who has granted medRxiv a license to display the preprint in perpetuity.

This article is a US Government work. It is not subject to copyright under 17 USC 105 and is also made available for use under a CCO license.

COVID diagnosis, and days since onset of the respiratory illness. We focused on "during illness"

231 ratings because those best showed evidence for the effects of illness and were also the most

232 predictive symptom in a previous study with the same questionnaire (9). Moreover, this question

233 (rather than pre-illness ratings or change in ratings) is best suited for being asked when making

234 an inventory of symptoms in a clinical setting.

\section{RESULTS}

\section{Participant Characteristics}

A total of 5156 participants reported a positive lab test for COVID-19 (hereafter, C19+),

239 while 659 reported a negative lab test for COVID-19 (hereafter, C19-). Of all participants, 519

240 (9\% of the total group) self-reported to have obesity $(\mathrm{C} 19+=433$; $\mathrm{C} 19-=86)$ (Figure 1). The

241 demographic profile of our participants is summarized in Supplementary Table 2 a and b. Age

242 is higher in $\mathrm{OB}+$ compared to $\mathrm{OB}-\left(43.1\right.$ vs 39.5) $\left(\mathrm{BF}_{10}=7.48 \mathrm{e}+06 \pm 0 \%\right)$. After excluding $\mathrm{n}=$

24317 participants with gender reporting categories of "prefer not to say" $(\mathrm{n}=13)$ and "other" $(\mathrm{n}=$

$2444)$, we observed different proportions of gender $\left(\chi^{2}=4.42, p=0.035\right)$, driven primarily by a

245 higher proportion of women in the C19- group with obesity (87.2\%) compared to those without 246 obesity $(77 \%)$.

248 Before COVID-19 illness, participants with obesity exhibit similar smell, taste, and

249 chemesthesis loss as those without obesity before COVID-19 illness

250 Before COVID-19 illness, OB+ participants did not self-report greater ability in smell

251 (change against zero, $\left.\mathrm{BF}_{10}=6.48 \mathrm{e}-02 \pm 0 \%\right)$, taste $\left(\mathrm{BF}_{10}=7.24 \mathrm{e}-02 \pm 0 \%\right.$ ) or chemesthesis

$252\left(\mathrm{BF}_{10}=7.89 \mathrm{e}-02 \pm 0 \%\right)$, or greater nasal congestion $\left(\mathrm{BF}_{10}=6.80 \mathrm{e}-02 \pm 0 \%\right)$ than $\mathrm{OB}-$ 
medRxiv preprint doi: https://doi.org/10.1101/2021.02.28.21252536; this version posted March 3, 2021. The copyright holder for this preprint (which was not certified by peer review) is the author/funder, who has granted medRxiv a license to display the preprint in perpetuity. This article is a US Government work. It is not subject to copyright under 17 USC 105 and is also made available for use under a CCO license.

$254 \mathrm{C} 19+$ participants reported greater ability in smell $\left(\mathrm{BF}_{10}=2.16 \mathrm{e}+01\right)$ and taste $\left(\mathrm{BF}_{10}=3.45 \mathrm{e}+02\right.$

$255 \pm 0 \%)$ than C19-participants.

During COVID-19 illness, participants with obesity exhibit similar smell, taste, and

against zero: $\mathrm{BF}_{10}=1.69 \mathrm{e}+05 \pm 0 \%$ ), as compared with $\mathrm{C} 19$ - participants (Figure 2,

Supplementary Table 4). Similar to our previous report (22), we reported lower deficits in nasal congestion with $\mathrm{C} 19+$ participants in our analysis (change against zero: $\mathrm{BF}_{10}=1.56 \mathrm{e}+01 \pm 0 \%$ ), participants who self-reported obesity vs participants without obesity (smell $\mathrm{BF}_{10}=1.44 \mathrm{e}-01 \pm$

$2660 \%$; taste $5.7 \mathrm{e}-02 \pm 0 \%$; chemesthesis $8.22 \mathrm{e}-01 \pm 0 \%$ ), across the COVID groups.

267 Similar to the above chemosensory findings during the illness, the differences in chemosensory 268 ratings between pre-and during illness varied in C19+ and C19-participants (Figure 3,

269 Supplementary Table 5). In particular, C19+ participants reported greater deficits in smell

270 (change against zero: $\mathrm{BF}_{10}=5.18 \mathrm{e}+59 \pm 0 \%$ ), taste (change against zero: $\mathrm{BF}_{10}=1.46 \mathrm{e}+32 \pm 0 \%$ ),

271 and chemesthesis (change against zero: $\mathrm{BF}_{10}=6.82 \mathrm{e}-+07 \pm 0 \%$ ), than the $\mathrm{C} 19$ - group. However,

272 when estimating the effect of obesity condition, the three chemosensory variables did not differ

273 between the groups with obesity and without obesity across the COVID-19 condition (smell

274 change against zero; $\mathrm{BF}_{10}=6.71 \mathrm{e}-02 \pm 0 \%$; taste change against zero $\mathrm{BF}_{10}=5.28 \mathrm{e}-02 \pm 0 \%$; 
medRxiv preprint doi: https://doi.org/10.1101/2021.02.28.21252536; this version posted March 3, 2021. The copyright holder for this preprint (which was not certified by peer review) is the author/funder, who has granted medRxiv a license to display the preprint in perpetuity.

This article is a US Government work. It is not subject to copyright under 17 USC 105 and is also made available for use under a CCO license.

chemesthesis change against zero $\mathrm{BF}_{10}=1.26 \mathrm{e}-01 \pm 0 \%$ ). Interestingly, there was no main effect of COVID-19 condition or obesity status on the nasal obstruction reporting.

278 Participants with obesity exhibit similar smell, taste, and chemesthesis recovery from COVID-19 illness as those without obesity

To further understand changes in chemosensory perception with COVID-19 diagnosis

281 and obesity condition, we looked at the data from participants who reported recovery from the

282 illness (Figure 4, Supplementary Table 6). Recovery was reported by 3970 participants

$283(\mathrm{n}=3431 \mathrm{C} 19+$ and $\mathrm{n}=539 \mathrm{C19}-)$, which is approximately $68 \%$ of our sample. Our Bayesian

284 linear models suggest that the ratings for post-recovery chemosensory perception $\left(\right.$ smell $^{\mathrm{B} F_{10}}=$

$2857.79 \mathrm{e}-02 \pm 0.02 \%$; taste $\mathrm{BF}_{10}=6.44 \mathrm{e}-02 \pm 0.02 \%$; chemesthesis $\left.\mathrm{BF}_{10}=2.18 \mathrm{e}-01 \pm 0.01 \%\right)$ did

286 not differ in C19+ and C19- diagnosis. Of note, some smell/taste/chemosensory symptoms

287 remain post-recovery from the illness in C19+ and C19-groups. We found no differences in 288 smell $\left(\mathrm{BF}_{10}=6.58 \mathrm{e}-02 \pm 0.02 \%\right)$, taste $\left(\mathrm{BF}_{10}=1.07 \mathrm{e}-01 \pm 0.02 \%\right)$, and chemesthetic perception

$289\left(\mathrm{BF}_{10}=9.96 \mathrm{e}-02 \pm 0.11 \%\right)$ by self-reported obesity. Nasal obstruction did not seem to be

290 affected by either COVID-19 diagnosis $\left(\mathrm{BF}_{10}=5.33 \mathrm{e}-02 \pm 0.03 \%\right)$ or obesity status $\left(\mathrm{BF}_{10}\right.$

$291=8.16 \mathrm{e}-02 \pm 0.02 \%)$ post-recovery from the illness.

293 Participants with obesity report more symptoms overall and more frequently report

294 respiratory and gastrointestinal (GI) symptoms.

Based on the evidence from existing clinical and epidemiological studies, one of our

296 goals was to assess whether individuals with self-reported obesity overall have greater

297 symptomatic manifestation with C19+ diagnosis than those participants without obesity. To test 
medRxiv preprint doi: https://doi.org/10.1101/2021.02.28.21252536; this version posted March 3, 2021. The copyright holder for this preprint (which was not certified by peer review) is the author/funder, who has granted medRxiv a license to display the preprint in perpetuity.

This article is a US Government work. It is not subject to copyright under 17 USC 105 and is also made available for use under a CCO license.

our hypothesis, we used Bayesian linear regression and compared the sum of the symptoms reported by participants in these samples versus samples without obesity (Figure 5A,

Supplementary Table 8). As predicted, among those with $\mathrm{C} 19+$, there is decisive evidence that

301 participants with obesity report a larger number of symptoms than participants without obesity

$302\left(\mathrm{BF}_{10}=1.02 \mathrm{e} 04 \pm 0 \%\right.$; average $\mathrm{N}$ of symptoms = with obesity: 8.22 ; without obesity: 7.42$) . \mathrm{A}$

303 similar effect is observed among participants with C19- (average $\mathrm{N}$ of symptoms = with obesity:

3048 ; without obesity: $7.33 \mathrm{BF}_{10}=9.91 \mathrm{e} 03 \pm 0 \%$ ). Among those with $\mathrm{C} 19+$, disease duration is

305 longer in those with obesity $\left(\mathrm{BF}_{10}=1.02 \mathrm{e} 04 \pm 0 \%\right.$; average days since onset), while in $\mathrm{C} 19$ - such

306 a difference is not observed $\left(\mathrm{BF}_{10}=1.21 \mathrm{e} 00 \pm 0 \%\right.$ (Figure 5B, Supplementary Table 7).

307 Looking at the specific symptoms (Figure 5C), smell and taste symptoms are equally reported

308 by participants with obesity and participants without obesity with a diagnosis of COVID-19.

309 Further, participants with self-reported obesity reported greater frequency in loss of appetite,

310 diarrhea, and nausea, along with shortness of breath, cough (dry or with mucus), and chest

311 tightness.

313 A classifier trained on participants without obesity accurately predicts C19+ diagnosis in

\section{4 participants with obesity}

315 Based on the self-reports on symptoms, combined with the chemosensory and nasal

316 obstruction ratings, we assessed the accuracy with which we could predict a C19+ diagnosis

317 (Figure 6) in OB-. We then tested the model to predict the accuracy of discrimination of C19+ in

318 participants with obesity. Our results indicate that we can predict the C19+ diagnosis with $63 \%$

319 accuracy, which indicates a moderately good estimate. Variables included in this analysis are

320 reported in Supplementary Table 8. 
medRxiv preprint doi: https://doi.org/10.1101/2021.02.28.21252536; this version posted March 3, 2021. The copyright holder for this preprint

(which was not certified by peer review) is the author/funder, who has granted medRxiv a license to display the preprint in perpetuity.

This article is a US Government work. It is not subject to copyright under 17 USC 105 and is also made available for use under a CCO license.

\section{DISCUSSION}

Since the beginning of the COVID-19 pandemic, reports of olfactory and gustatory

324 dysfunctions in COVID-19 patients continue to grow. To our knowledge, this study is the first to

325 describe and compare the chemosensory perception and related symptomatology in COVID-19

326 patients who self-reported to have obesity vs. no obesity. Independent of the obesity status, the

327 subjective ratings of smell, taste, and chemesthesis declined with COVID-19 illness. Examining

328 the recovery patterns, we found that participants with obesity show similar recovery from

329 COVID-19 related loss of smell, taste, and chemesthesis as those without obesity. Although we

330 do not know the severity of each symptom, those with obesity reported a greater frequency of

331 respiratory and GI symptoms and more symptoms overall. Finally, we found that a model of all

332 symptoms combined that was trained on patients without obesity is, can predict the C19+

333 diagnosis with $63 \%$ of accuracy in participants with obesity. Furthermore, this smell loss was not

334 related to self-reported nasal obstruction, commonly observed in other upper respiratory

335 infections $(33,34)$. Together, these results confirm and add to previous reports that COVID-19

336 largely impacts chemosensory function; however, obesity does not mask self-reported

337 chemosensory loss in those with a COVID diagnosis.

338 Smell and taste disturbances are a typical consequence of nasal inflammation due to an

339 upper respiratory tract viral infection $(35,36)$; however, an acute loss of taste and smell emerged

340 rapidly as a critical neurological manifestation of a positive COVID-19 diagnosis (37). Our

341 current findings are similar to prior reports that showed that approximately $90 \%$ of the

342 participants reported a loss of smell. Furthermore, nearly $80 \%$ of the participants reported a loss

343 of taste, and $46 \%$ had a reduction of chemesthesis (detection of chemicals that induce tingling 
medRxiv preprint doi: https://doi.org/10.1101/2021.02.28.21252536; this version posted March 3, 2021. The copyright holder for this preprint

(which was not certified by peer review) is the author/funder, who has granted medRxiv a license to display the preprint in perpetuity.

This article is a US Government work. It is not subject to copyright under 17 USC 105 and is also made available for use under a CCO license.

344 and burning sensations such as the burning of chili peppers), indicating that the chemosensory

345 impairment is not restricted to smell $(9,22)$. While most cold viruses cause nasal congestion and

346 individuals experience a reduction in the sense of smell, our results showed that nasal congestion

347 was not associated with smell loss. This finding is consistent with other reports (38-40) where

348 individuals with COVID-19 do not report clinically significant nasal congestion or rhinorrhea,

349 suggesting that other mechanisms may play a role in COVID-19 associated smell loss (37).

350 In addition to being a risk factor for COVID-19 viral infection, excessive body weight is

351 also implicated in chemosensory decline. Adipose tissue in obesity is "pro-inflammatory",

352 causing a surge in levels of IL-6 and C-reactive protein and enhancing the expression of

353 cytokines and adipokines (41). Interestingly, in diseases where these circulating inflammatory

354 factors are high, smell and taste dysfunction are prevalent $(42,43)$. In particular, acute induction

355 of systemic inflammation has been shown to shorten the lifespan of adult taste bud cells (18).

356 Similarly, enhanced expression of inflammatory markers is shown to reduce olfactory sensory

357 neurons, in mice fed a high-fat diet to induce obesity (44). Thus, obesity-related inflammation

358 may affect chemosensory function. A major concern with this pre-existing gustatory and

359 olfactory sensory deficiency due to obesity is that obesity may mask the viral-induced

360 diminished taste and smell self-reported experiences. Interestingly, our analysis showed that

361 COVID-19 related chemosensory-related changes were comparable between C19+ participants

362 with obesity and without obesity suggesting that obesity does not have an effect on the loss of

363 chemosensory perception with COVID diagnosis. These findings need to be taken with caution,

364 especially when considering severe cases, which are more common in patients with obesity. For

365 example, if a patient is in critical condition, they cannot pay attention to their chemosensory 
medRxiv preprint doi: https://doi.org/10.1101/2021.02.28.21252536; this version posted March 3, 2021. The copyright holder for this preprint (which was not certified by peer review) is the author/funder, who has granted medRxiv a license to display the preprint in perpetuity. This article is a US Government work. It is not subject to copyright under 17 USC 105 and is also made available for use under a CCO license.

alterations, and chemosensory perception will likely not be tested or self-reported. This does not mean that the chemosensory perception is not affected.

In terms of chemosensory recovery, we found no differences between participants with

369 obesity compared to those without obesity. While none of the studies to date have compared the

370 recovery rates between $\mathrm{C} 19+$ participants with obesity vs no obesity, our overall recovery rate of

$37165 \%$ is comparable to our previous analysis (9) but slightly lower than other studies $(45,46)$.

372 There are residuals smell/taste/chemosensory symptoms reported post-recovery from the illness

373 in C19+ and C19- groups. In particular, quantitative studies using psychophysical methods have

374 shown that nearly $25 \%$ of people continue to report chemosensory problems when evaluated 30 -

37560 days after the onset of COVID-19 (45). This insufficient recovery rate may significantly

376 increase the number of patients with chemosensory disturbances, ultimately influencing eating

377 behaviors (47), quality of life $(48,49)$, and psychological health $(50,51)$ in the general population.

378 But most importantly, it may significantly impact participants with obesity who have an added

379 burden of lower chemosensory acuity due to excess fat mass $(44,52)$. Thus, it is imperative to

380 prepare healthcare workers to detect and treat chemosensory disorders in this high-risk

381 population.

As we hypothesized, non-chemosensory symptoms were more severe in C19+

383 participants with obesity than in participants without obesity. Specifically, participants with

384 obesity reported a greater frequency of respiratory and GI symptoms. In general, it is known that

385 obesity is associated with GI symptoms disturbances, such as upper abdominal pain, nausea,

386 vomiting, retching, and gastritis. GI symptoms are accompanied by inflammation or alterations

387 of intestinal permeability (53-56). However, it also emerged that COVID-19 patients

388 experienced several GI symptoms such as diarrhea (24.2\%), anorexia (17.9\%), and nausea 
medRxiv preprint doi: https://doi.org/10.1101/2021.02.28.21252536; this version posted March 3, 2021. The copyright holder for this preprint

(which was not certified by peer review) is the author/funder, who has granted medRxiv a license to display the preprint in perpetuity.

This article is a US Government work. It is not subject to copyright under 17 USC 105 and is also made available for use under a CCO license.

(17.9\%) (57), though they vary widely and are less understood. However, this may not be

surprising since some viral infections are known to cause alterations in intestinal permeability as and large intestines (59-63).

Our study has some limitations. Our online survey and sampling methodology likely nature of our data being collected in several countries, the definition of obesity may vary and there may be regional and cultural factors that may influence stigma and biases towards self-

401 report of obesity. Ideally, future studies using quantitative taste and smell measures will be 402 conducted in this population. However, although the taste and smell reports were also self-

403 reports, similar to prior studies, we demonstrate that self-reported taste and smell may be a

404 helpful tool to distinguish between C19+ and C19-.

406 compared to participants without obesity with other symptoms. However, those differences

407 potentially do not affect the chemosensory symptoms. In general, more evidence is needed to

408 understand biological mechanisms related to alterations in taste and smell loss in individuals

409 with COVID-19. Understanding how the alteration initiates and progresses will provide

410 molecular and cellular bases for diagnosis and treatment of chemosensory disorders for those

411 with COVID-19 and others who lose their sense of taste and smell due to other conditions with 
medRxiv preprint doi: https://doi.org/10.1101/2021.02.28.21252536; this version posted March 3, 2021. The copyright holder for this preprint (which was not certified by peer review) is the author/funder, who has granted medRxiv a license to display the preprint in perpetuity.

This article is a US Government work. It is not subject to copyright under 17 USC 105 and is also made available for use under a CCO license.

412 underlying inflammation. While it is an exciting prospect, the use of chemosensory assessments

413 as an effective tool for screening and treatment protocols, and the possibility of integrating these

414 tests into current COVID-19 screening protocols have yet to be determined in the general

415 population, as well as high-risk populations with obesity.

\section{Acknowledgments}

418 The authors wish to thank all study participants, patients, and patient advocates that have

419 contributed to this project.

\section{REFERENCES}

422 1. Obesity and overweight [Internet]. World Health Organization Fact Sheet Obesity and 423 Overweight. 2021 [cited 2021 Jan 25]. Available from: https://www.who.int/news-

$424 \quad$ room/fact-sheets/detail/obesity-and-overweight

425 2. Max Roser EO-O Hannah Ritchie, Hasell J. Coronavirus Pandemic (COVID-19). Our

$426 \quad$ World Data. 2020;

427 3. Stefan N, Birkenfeld AL, Schulze MB. Global pandemics interconnected - obesity, 428 impaired metabolic health and COVID-19. Nat Rev Endocrinol. 2021 Jan 21;

429 4. Williamson EJ, Walker AJ, Bhaskaran K, Bacon S, Bates C, Morton CE, et al. Factors $430 \quad$ associated with COVID-19-related death using OpenSAFELY. Nature. 2020

$431 \quad$ Aug;584(7821):430-6.

432 5. Kalligeros M, Shehadeh F, Mylona EK, Benitez G, Beckwith CG, Chan PA, et al. 433 Association of Obesity with Disease Severity Among Patients with Coronavirus Disease 434 2019. Obesity. 2020;28(7):1200-4. 
medRxiv preprint doi: https://doi.org/10.1101/2021.02.28.21252536; this version posted March 3, 2021. The copyright holder for this preprint

(which was not certified by peer review) is the author/funder, who has granted medRxiv a license to display the preprint in perpetuity.

This article is a US Government work. It is not subject to copyright under 17 USC 105 and is also made available for use under a CCO license.

6. Zhu X, Yang L, Huang K. COVID-19 and Obesity: Epidemiology, Pathogenesis and Treatment. Diabetes Metab Syndr Obes Targets Ther. 2020 Dec 14;13:4953-9.

437 7. Lighter J, Phillips M, Hochman S, Sterling S, Johnson D, Francois F, et al. Obesity in

438 Patients Younger Than 60 Years Is a Risk Factor for COVID-19 Hospital Admission. Clin 439 Infect Dis Off Publ Infect Dis Soc Am. 2020 28;71(15):896-7.

440 8. Hannum ME, Ramirez VA, Lipson SJ, Herriman RD, Toskala AK, Lin C, et al. Objective $441 \quad$ Sensory Testing Methods Reveal a Higher Prevalence of Olfactory Loss in COVID-19Positive Patients Compared to Subjective Methods: A Systematic Review and MetaAnalysis. Chem Senses. 2020 Dec 5;45(9):865-74.

9. Gerkin RC, Ohla K, Veldhuizen MG, Joseph PV, Kelly CE, Bakke AJ, et al. Recent smell loss is the best predictor of COVID-19 among individuals with recent respiratory symptoms. Chem Senses [Internet]. 2020 Dec 25 [cited 2021 Jan 13];(bjaa081). Available

10. Uygun B, Kiyici S, Ozmen S, Gul Z, Sigirli D, Cavun S. The Association Between Olfaction and Taste Functions with Serum Ghrelin and Leptin Levels in Obese Women. Metab Syndr Relat Disord. 2019 Nov;17(9):452-7.

451 11. Tucker RM, Edlinger C, Craig BA, Mattes RD. Associations Between BMI and Fat Taste Sensitivity in Humans. Chem Senses. 2014 May 1;39(4):349-57.

453 12. Bertoli S, Laureati M, Battezzati A, Bergamaschi V, Cereda E, Spadafranca A, et al. Taste sensitivity, nutritional status and metabolic syndrome: Implication in weight loss dietary interventions. World J Diabetes. 2014 Oct 15;5(5):717-23. 
medRxiv preprint doi: https://doi.org/10.1101/2021.02.28.21252536; this version posted March 3, 2021. The copyright holder for this preprint

(which was not certified by peer review) is the author/funder, who has granted medRxiv a license to display the preprint in perpetuity.

This article is a US Government work. It is not subject to copyright under 17 USC 105 and is also made available for use under a CCO license.

14. Fernández-Aranda F, Agüera Z, Fernández-García JC, Garrido-Sanchez L, Alcaide-Torres

J, Tinahones FJ, et al. Smell-taste dysfunctions in extreme weight/eating conditions: analysis of hormonal and psychological interactions. Endocrine. 2016 Feb;51(2):256-67.

461 15. Fernandez-Garcia JC, Alcaide J, Santiago-Fernandez C, Roca-Rodriguez MM, Aguera Z, Baños R, et al. An increase in visceral fat is associated with a decrease in the taste and olfactory capacity. PloS One. 2017;12(2):e0171204.

16. Thiebaud N, Johnson MC, Butler JL, Bell GA, Ferguson KL, Fadool AR, et al. Hyperlipidemic diet causes loss of olfactory sensory neurons, reduces olfactory discrimination, and disrupts odor-reversal learning. J Neurosci Off J Soc Neurosci. 2014 May 14;34(20):6970-84.

17. Besnard P, Passilly-Degrace P, Khan NA. Taste of Fat: A Sixth Taste Modality? Physiol Rev. 2016 Jan;96(1):151-76.

19. Huttunen R, Syrjänen J. Obesity and the outcome of infection. Lancet Infect Dis. 2010 Jul;10(7):442-3.

474 20. Nave H, Beutel G, Kielstein JT. Obesity-related immunodeficiency in patients with pandemic influenza H1N1. Lancet Infect Dis. 2011 Jan;11(1):14-5.

478 22. Parma V, Ohla K, Veldhuizen MG, Niv MY, Kelly CE, Bakke AJ, et al. More Than 479 Smell — COVID-19 Is Associated With Severe Impairment of Smell, Taste, and 480 Chemesthesis. Chem Senses. 2020 Oct 9;45(7):609-22. 
medRxiv preprint doi: https://doi.org/10.1101/2021.02.28.21252536; this version posted March 3, 2021. The copyright holder for this preprint

(which was not certified by peer review) is the author/funder, who has granted medRxiv a license to display the preprint in perpetuity.

This article is a US Government work. It is not subject to copyright under 17 USC 105 and is also made available for use under a CCO license.

23. Menni C, Valdes AM, Freidin MB, Sudre CH, Nguyen LH, Drew DA, et al. Real-time tracking of self-reported symptoms to predict potential COVID-19. Nat Med. 2020;26:1037-40.

24. Foster KJ, Jauregui E, Tajudeen B, Bishehsari F, Mahdavinia M. Smell loss is a prognostic factor for lower severity of coronavirus disease 2019. Ann Allergy Asthma Immunol. 2020 Oct $1 ; 125(4): 481-3$

25. Reiner RC, Barber RM, Collins JK, Zheng P, Adolph C, Albright J, et al. Modeling COVID-19 scenarios for the United States. Nat Med. 2020 Oct 23;1-12.

26. Bhutani S, Parma V, Joseph PV, Coppin G, Veldhuizen M. Chemosensory dysfunction as a reliable marker for COVID-19 in adults with self-reported obesity [Internet]. 2020. Available from: osf.io/xf25v

27. Team R Core Development. R: The R Project for Statistical Computing [Internet]. 2013 [cited 2021 Feb 9]. Available from: https://www.r-project.org/ Bayes Factors for Common Designs [Internet]. 2018 [cited 2021 Feb 9]. Available from:

29. Lee MD, Wagenmakers E-J. Bayesian Cognitive Modeling: A Practical Course [Internet]. Cambridge: Cambridge University Press; 2013 [cited 2020 Jul 19]. Available from: http://ebooks.cambridge.org/ref/id/CBO9781139087759

501 31. Lunardon N, Menardi G, Torelli N. ROSE: a Package for Binary Imbalanced Learning. R J. 2014;6(1):79.

503 32. Robin X, Turck N, Hainard A, Tiberti N, Lisacek F, Sanchez J-C, et al. pROC: an open- 
medRxiv preprint doi: https://doi.org/10.1101/2021.02.28.21252536; this version posted March 3, 2021. The copyright holder for this preprint

(which was not certified by peer review) is the author/funder, who has granted medRxiv a license to display the preprint in perpetuity.

This article is a US Government work. It is not subject to copyright under 17 USC 105 and is also made available for use under a CCO license.

source package for $\mathrm{R}$ and $\mathrm{S}+$ to analyze and compare ROC curves. BMC Bioinformatics. 2011 Mar 17;12(1):77.

33. Akerlund A, Bende M, Murphy C. Olfactory threshold and nasal mucosal changes in experimentally induced common cold. Acta Otolaryngol (Stockh). 1995 Jan;115(1):88-92.

34. Doty RL, Mishra A. Olfaction and Its Alteration by Nasal Obstruction, Rhinitis, and Rhinosinusitis. The Laryngoscope. 2001;111(3):409-23.

35. Soler ZM, Patel ZM, Turner JH, Holbrook EH. A primer on viral-associated olfactory loss in the era of COVID-19. Int Forum Allergy Rhinol. 2020;10(7):814-20.

36. Hummel T, Landis BN, Hüttenbrink K-B. Smell and taste disorders. GMS Curr Top Otorhinolaryngol Head Neck Surg. 2011;10:Doc04.

514 37. Cooper KW, Brann DH, Farruggia MC, Bhutani S, Pellegrino R, Tsukahara T, et al. COVID-19 and the chemical senses: supporting players take center stage. Neuron [Internet]. $2020 \mathrm{Jul}$ [cited $2020 \mathrm{Jul} 2$ ]; Available from:

38. Mao L, Jin H, Wang M, Hu Y, Chen S, He Q, et al. Neurologic Manifestations of Hospitalized Patients With Coronavirus Disease 2019 in Wuhan, China [Internet]. JAMA Neurology. 2020. Available from:

39. Mao L, Wang M, Chen S, He Q, Chang J, Hong C, et al. Neurological Manifestations of Hospitalized Patients with COVID-19 in Wuhan, China: a retrospective case series study. medRxiv. 2020;2020.02.22.20026500.

40. Li Y, Bai W, Hashikawa T. The neuroinvasive potential of SARS $\square$ CoV2 may be at least partially responsible for the respiratory failure of COVID $\square 19$ patients [Internet]. Journal of 
medRxiv preprint doi: https://doi.org/10.1101/2021.02.28.21252536; this version posted March 3, 2021. The copyright holder for this preprint

(which was not certified by peer review) is the author/funder, who has granted medRxiv a license to display the preprint in perpetuity.

This article is a US Government work. It is not subject to copyright under 17 USC 105 and is also made available for use under a CCO license.

Medical Virology. 2020. Available from:

https://onlinelibrary.wiley.com/doi/abs/10.1002/jmv.25728

529 41. Heredia FP de, Gómez-Martínez S, Marcos A. Obesity, inflammation and the immune

$530 \quad$ system. Proc Nutr Soc. 2012 May;71(2):332-8.

531 42. Rawson NE, Huang L. Symposium Overview. Ann N Y Acad Sci. 2009;1170(1):581-4.

532 43. Wang H, Zhou M, Brand J, Huang L. Inflammation and Taste Disorders. Vol. 1170, Annals

533 of the New York Academy of Sciences. 2009. p. 596-603.

534 44. Riera CE, Tsaousidou E, Halloran J, Follett P, Hahn O, Pereira MMA, et al. The Sense of

535 Smell Impacts Metabolic Health and Obesity. Cell Metab. 2017 Jul 5;26(1):198-211.e5.

536 45. Niklassen AS, Draf J, Huart C, Hintschich C, Bocksberger S, Trecca EMC, et al. COVID-

537 19: Recovery from Chemosensory Dysfunction. A Multicentre study on Smell and Taste.

538 The Laryngoscope. 2021 Jan 6;

539 46. Reiter ER, Coelho DH, Kons ZA, Costanzo RM. Subjective smell and taste changes during

540 the COVID-19 pandemic: Short term recovery. Am J Otolaryngol. 2020 Dec;41(6):102639.

541 47. Kershaw JC, Mattes RD. Nutrition and taste and smell dysfunction. World J

542 Otorhinolaryngol - Head Neck Surg. 2018 Mar 1;4(1):3-10.

543 48. Smeets MAM, Veldhuizen MG, Galle S, Gouweloos J, de Haan A-MJA, Vernooij J, et al.

$544 \quad$ Sense of smell disorder and health-related quality of life. Rehabil Psychol. 2009

$545 \quad$ Nov;54(4):404-12.

546 49. Croy I, Nordin S, Hummel T. Olfactory disorders and quality of life--an updated review.

547 Chem Senses. 2014 Mar;39(3):185-94.

548 50. Malaty J, Malaty IAC. Smell and taste disorders in primary care. Am Fam Physician. 2013

$549 \quad$ Dec 15;88(12):852-9. 
medRxiv preprint doi: https://doi.org/10.1101/2021.02.28.21252536; this version posted March 3, 2021. The copyright holder for this preprint

(which was not certified by peer review) is the author/funder, who has granted medRxiv a license to display the preprint in perpetuity.

This article is a US Government work. It is not subject to copyright under 17 USC 105 and is also made available for use under a CCO license.

51. Croy I, Symmank A, Schellong J, Hummel C, Gerber J, Joraschky P, et al. Olfaction as a marker for depression in humans. J Affect Disord. 2014 May 1;160:80-6.

552 52. Peng M, Coutts D, Wang T, Cakmak YO. Systematic review of olfactory shifts related to $553 \quad$ obesity. Obes Rev. 2019;20(2):325-38.

554 53. Nam SY. Obesity-Related Digestive Diseases and Their Pathophysiology. Gut Liver. 2017

$555 \quad$ May 15;11(3):323-34.

556 54. Camilleri M, Malhi H, Acosta A. Gastrointestinal Complications of Obesity.

557 Gastroenterology. 2017 May 1;152(7):1656-70.

558 55. Nagpal R, Newman TM, Wang S, Jain S, Lovato JF, Yadav H. Obesity-Linked Gut

559 Microbiome Dysbiosis Associated with Derangements in Gut Permeability and Intestinal

560 Cellular Homeostasis Independent of Diet. Fiorina P, editor. J Diabetes Res. 2018 Sep

$561 \quad 3 ; 2018: 3462092$.

562 56. Moss O, Keshavarzian A, Tangney C, Shawron K, Kester K, Shaikh M, et al. Headache, GI symptoms and Intestinal Permeability in Obese Adults. FASEB J. 2016;30(S1):1166.71166.7.

57. Lin L, Jiang X, Zhang Z, Huang S, Zhang Z, Fang Z, et al. Gastrointestinal symptoms of 95 cases with SARS-CoV-2 infection. Gut. 2020 Jun 1;69(6):997-1001.

567 58. Labarta-Bajo L, Nilsen SP, Humphrey G, Schwartz T, Sanders K, Swafford A, et al. Type I IFNs and CD8 T cells increase intestinal barrier permeability after chronic viral infection. $\mathrm{J}$ Exp Med [Internet]. 2020 Sep 3 [cited 2021 Feb 19];217(e20192276). Available from: https://doi.org/10.1084/jem.20192276

59. Jin X, Lian J-S, Hu J-H, Gao J, Zheng L, Zhang Y-M, et al. Epidemiological, clinical and virological characteristics of 74 cases of coronavirus-infected disease 2019 (COVID-19) 
medRxiv preprint doi: https://doi.org/10.1101/2021.02.28.21252536; this version posted March 3, 2021. The copyright holder for this preprint

(which was not certified by peer review) is the author/funder, who has granted medRxiv a license to display the preprint in perpetuity.

This article is a US Government work. It is not subject to copyright under 17 USC 105 and is also made available for use under a CCO license.

with gastrointestinal symptoms. Gut. 2020 Jun;69(6):1002-9.

574 60. Parasa S, Desai M, Thoguluva Chandrasekar V, Patel HK, Kennedy KF, Roesch T, et al.

575 Prevalence of Gastrointestinal Symptoms and Fecal Viral Shedding in Patients With

$576 \quad$ Coronavirus Disease 2019: A Systematic Review and Meta-analysis. JAMA Netw Open.

2020 Jun 11;3(6):e2011335-e2011335.

578 61. Villapol S. Gastrointestinal symptoms associated with COVID-19: impact on the gut microbiome. Transl Res. 2020 Dec 1;226:57-69.

62. Hamming I, Timens W, Bulthuis MLC, Lely AT, Navis GJ, Goor H van. Tissue distribution of ACE2 protein, the functional receptor for SARS coronavirus. A first step in understanding SARS pathogenesis. J Pathol. 2004;203(2):631-7.

63. Li M-Y, Li L, Zhang Y, Wang X-S. Expression of the SARS-CoV-2 cell receptor gene ACE2 in a wide variety of human tissues. Infect Dis Poverty. 2020 Apr 28;9(1):45.

Figure 1. Flow Diagram of Study Participants Based on the STrengthening the Reporting of OBservational Studies in Epidemiology (STROBE) guidelines. Participants included in the

591 prediction of COVID-19 status in participants with obesity vs without obesity are framed in blue.

592 Participants framed in purple are included in all other analyses. $n=$ number of participants; OB+

593 = self-reported presence of obesity; OB- = self-reported presence of obesity; COVID diagnosis

594 unclear = responses "No - I do not have any symptoms", "Don’t know" or "Other" to survey

595 Question 8 (“Have you been diagnosed with COVID-19?”). 
medRxiv preprint doi: https://doi.org/10.1101/2021.02.28.21252536; this version posted March 3, 2021. The copyright holder for this preprint (which was not certified by peer review) is the author/funder, who has granted medRxiv a license to display the preprint in perpetuity. This article is a US Government work. It is not subject to copyright under 17 USC 105 and is also made available for use under a CCO license.

Figure 2. Self-reported smell (A), taste (B), chemesthesis (C), and nasal obstruction (D) ratings during the illness in $\mathrm{C} 19+$ (in purple) and C19- (in blue) participants with obesity (OB+) or without obesity (OB-). Ratings were given on 0-100 visual analog scales. Nasal obstruction question was formulated as "How blocked was your nose?") during respiratory illness in C19+ and C19- participants. Each panel presents the mean ratings for chemosensory abilities and nasal blockage. All participants had a diagnosis via a lab test. The thick black horizontal bar indicates the median, the shaded bars within each violin indicates the interquartile range. The shaded violin area in purple and blue represents smoothed histogram of data density along the data points.

Figure 3. Self-reported change in smell (A), taste (B), chemesthesis (C), and nasal obstruction (D) ratings in $\mathrm{C} 19+$ (in purple) and $\mathrm{C} 19$ - (in blue) participants with obesity $(\mathrm{OB}+$ ) or without

611 obesity (OB-). Each panel presents the distribution of the change scores, i.e., the rating "before"

612 illness minus the rating "during" illness on the 100-point visual analog scale. All participants had

613 a diagnosis via a lab test. The thick black horizontal bar indicates the median, the shaded bars

614 within each violin indicates the interquartile range. The shaded violin area in purple and blue 615 represents smoothed histogram of data density along the data points.

618 Figure 4. Self-reported change in smell (A), taste (B), chemesthesis (C), and nasal obstruction

619 (D) ratings post-recovery from respiratory illness in C19+ (in purple) and C19- (in blue)

620 participants with obesity (OB+) or without obesity (OB-). Ratings were given on 0-100 visual

621 analog scales. Each panel presents the mean ratings for chemosensory abilities and nasal

622 blockage post-recovery from respiratory illness. All participants had a diagnosis via a lab

623 test. The thick black horizontal bar indicates the median, the shaded bars within each violin

624 indicates the interquartile range. The shaded violin area in purple and blue represents smoothed

625 histogram of data density along the data points. 
medRxiv preprint doi: https://doi.org/10.1101/2021.02.28.21252536; this version posted March 3, 2021. The copyright holder for this preprint (which was not certified by peer review) is the author/funder, who has granted medRxiv a license to display the preprint in perpetuity.

This article is a US Government work. It is not subject to copyright under 17 USC 105 and is also made available for use under a CCO license.

628 Figure 5. Self-reported symptomatic manifestation reported by C19+ (in purple) and C19- (in 629 blue) participants with obesity (OB+) or without obesity (OB-). (A) Cumulative number of

630 symptoms reported by $\mathrm{C} 19+$ (in purple) and C19- (in blue) participants with obesity $(\mathrm{OB}+$ ) or 631 without obesity (OB-).

632 (B) Self-reported average number of days since onset of respiratory illness symptoms reported 633 by $\mathrm{C} 19+$ (in purple) and C19- (in blue) participants with obesity (OB+) or without obesity (OB-).

634 (C) Proportion of participants with C19+ that report specific symptoms by self-reported obesity $635(\mathrm{OB}+)$ or without obesity $(\mathrm{OB}-){ }^{*} \mathrm{p}<0.05$. The thick black horizontal bar indicates the median, 636 the shaded bars within each violin indicates the interquartile range. The shaded violin area in 637 purple and blue represents smoothed histogram of data density along the data points.

640 Figure 6. ROC curve in discriminating C19+ vs. C19- in participants with obesity (OB+) after 641 having trained the model with participants without obesity (OB-). 


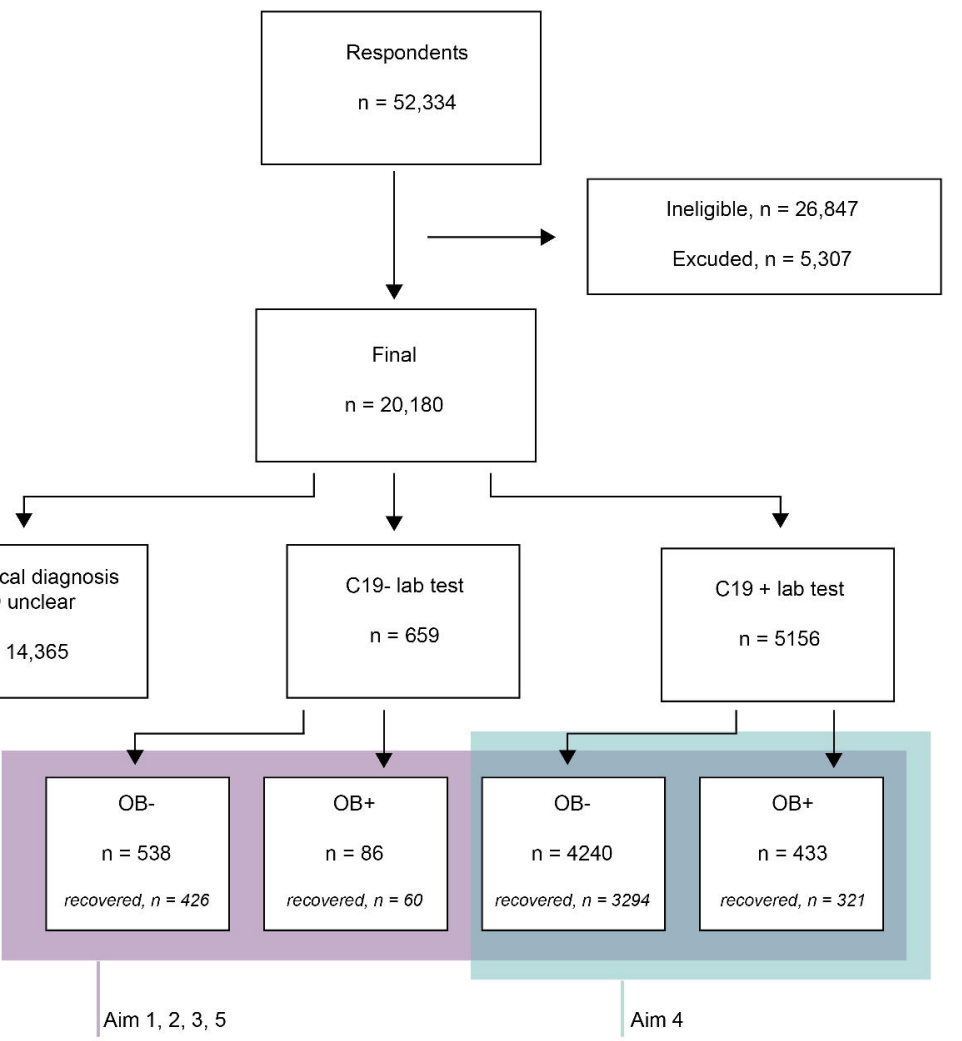




$$
\frac{414}{19}
$$




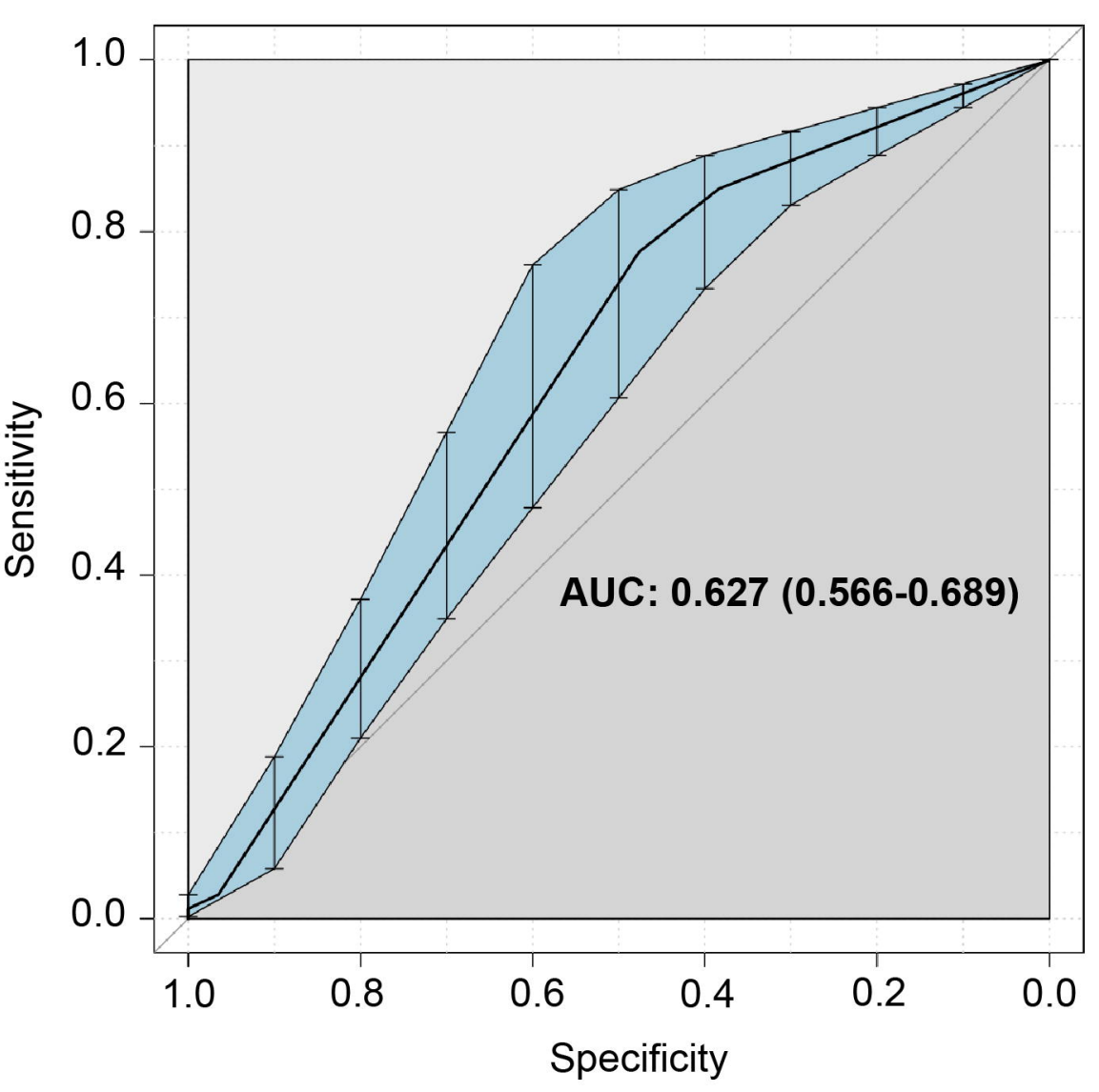

